\title{
PENGEMBANGAN MODUL PRAKTIKUM MANDIRI SEBAGAI ASESMEN KETERAMPILAN PROSES SAINS DAN KETERAMPILAN SOSIAL MAHASISWA
}

\author{
Fatkhur Rohman ${ }^{1}$ dan Ayu Lusiyana ${ }^{2}$ \\ 1,2 STKIP Nurul Huda Sukaraja OKU Timur \\ JI Kota Baru Sukaraja Kec. Buay Madang Kab. OKU Timur \\ *E-mail: ${ }^{1}$ Fatkhur@stkipnurulhuda.ac.id, ${ }^{2}$ Ayu.lusiyana@live.com
}

\begin{abstract}
Abstrak
Penelitian ini bertujuan untuk mengetahui keterlaksanaan pengembangan modul praktikum mandiri yang digunakan sebagai asesmen keterampilan proses sains dan keterampilan sosial mahasiswa. Subjek dalam penelitian ini adalah mahasiswa Pendidikan Fisika STKIP Nurul Huda Sukaraja semester 2 Tahun Akademik 2017/2018 berjumlah 19 mahasiswa. Penelitian ini merupakan penelitian (research and development), adapun model pengembangan yang digunakan adalah model 4-D. Metode pengumpulan data penelitian dengan kuesioner, dan observasi. Hasil penelitian menunjukkan bahwa modul praktikum mandiri yang dihasilkan secara keseluruhan dari penilaian aspek kelayakan isi, kebahasaan, kegrafikan, kemanfaatan produk, dan keterlaksanaan pratikum diperoleh nilai rata-rata skor total 3,65 dari penilaian teman sejawat, dan nilai rata-rata skor total 3,64 penilaian dari responden pengguna. Nilai tersebut mengindikasikan modul yang dikembangkan sangat layak digunakan dalam proses perkuliahan. Hasil asesmen keterampilan proses sains mahasiswa diperoleh nilai rerata total 3,19 yang mengindikasikan baik, sedangkan didapatkan nilai rerata total 3,53 dengan indikasi sangat baik pada penilaian keterampilan sosial mahasiswa.
\end{abstract}

Kata kunci: Modul Praktikum Mandiri, Keterampilan Proses Sains dan Keterampilan Sosial.

\section{PENDAHULUAN}

Kemajuan suatu bangsa tidak terlepas dari faktor pendidikan yang memiliki peran penting dalam usaha meningkatkan sumber daya manusia. Dalam UU Nomor 20 tahun 2003 tentang sistem pendidikan dinyatakan bahwa penyelenggara pendidikan wajib memegang beberapa prinsip yaitu pendidikan diselenggarakan secara demokratis dan berkeadilan serta tidak diskriminatif dengan menjunjung tinggi hak asasi manusia, nilai keagamaan, nilai kultural, dan kemajuan bangsa dengan satu kesatuan yang sistemik dengan sistem terbuka dan multimakna. Selain itu penyelenggaraan pendidikan juga harus dalam suatu proses pembudayaan dan pemberdayaan peserta didik yang berlangsung sepanjang hayat dengan memberi keteladanan, membangun kemauan, dan mengembangkan kreativitas peserta didik sebagai pengendalian mutu pendidikan. Melalui tujuan pendidikan tersebut, menjadi kewajiban bagi mahasiswa di jurusan pendidikan sebagai calon pendidik yang profesional untuk mampu membekali diri dengan kemampuan, kapabilitas dan keterampilan-keterampilan sosial yang diperoleh melalui perkuliahan di perguruan tinggi.

Sekolah Tinggi Keguruan dan IImu Pendidikan (STKIP) Nurul Huda Sukaraja merupakan salah satu lembaga perguruan tinggi di kopertis wilayah II yang menyediakan lingkungan pendidikan, memberikan kesempatan bagi mahasiswa untuk melakukan berbagai kegiatan belajar sehingga mahasiswa memperoleh pengalaman pembelajaran. Pembelajaran adalah suatu usaha yang sengaja melibatkan dan menggunakan profesional yang dimiliki pendidik untuk mencapai tujuan kurikulum (Isriani, 2012:10).

Tujuan pembelajaran ini akan mencapai hasil yang maksimal apabila pembelajaran berjalan secara efektif. Wragg (Dalam Jihad, 2010:12) menjelaskan bahwa pembelajaran 
yang efektif adalah pembelajaran yang memudahkan peserta didik untuk mempelajari sesuatu yang bermanfaat seperti fakta, keterampilan sains, nilai, konsep dan bagaimana hidup serasi dengan sesama (keterampilan sosial), atau suatu hasil yang diinginkan. Dosen sebagai pihak yang melakukan pembelajaran dan mahasiswa sebagai pihak yang melakukan kegiatan belajar, keduanya akan berinteraksi dan berjalan dengan baik apabila dosen dapat menciptakan suasana belajar yang kondusif dan relevan dengan tujuan yang hendak dicapai melalui proses pembelajaran praktikum.

Dosen sangat berperan penting dalam proses perkuliahan, sehingga pendidik harus mempunyai persiapan yang baik dan benar sebelum proses perkuliahan dilaksanakan. Persiapan yang dimaksud adalah tersedianya alat dan modul praktikum yang digunakan sebagai panduan kegiatan praktikum untuk mencapai hasil pembelajaran dipandang penting. Menurut Breg dalam (Rohman, 2015:4) terdapat tiga keunggulan kegiatan eksperimen dari segi pendidikan yaitu:

1. Mahasiswa lebih terlibat karena mereka sendiri yang melaksanakan kegiatan percoban yang dibimbing oleh pendidik.

2. Kegiatan eksperimen dapat melatih mahasiswa untuk berfikir kritis terhadap masalah yang dihadapi saat kegiatan eksperimen berlangsung.

3. Mahasiswa memperoleh keterampilan dalam menggunakan peralatan eksperimen.

Berdasarkan tiga keunggulan tersebut sangat tepat jika diterapkan dalam proses pembelajaran di STKIP Nurul Huda Sukaraja Pogram Studi Pendidikan Fisika agar menghasilkan potensi lulusan mahasiswa dapat mencapai kualitas yang optimal sesuai dengan Kompetensi Lulusan kurikulum 2013 yang mengharuskan adanya perubahan predikat dari keseimbangan soft skills dan hard skills yang meliputi aspek kompetensi sikap, keterampilan dan pengetahuan (Debdikbud, 2013 No 54).

Kurikulum 2013 dikembangkan dengan penyempurnaan kurikulum KTSP. Kurikulum 2013 dalam proses pembelajarannya dengan ciri utama mengarah kepada proses pendekatan saintifik $5 \mathrm{M}$ (Mengamati, Menanya, Mencoba, Mengasosiasikan, dan Mengkomunikasikan). Arah pendekatan ini merupakan bentuk sederhana dari keterampilan proses sains dan keterampilan sosial yang harus dimiliki oleh mahasiswa lulusan STKIP Nurul Huda progam studi pendidikan fisika sesuai dengan visinya menghasilkan tenaga pendidik Fisika yang profesional, inspiratif, inovatif, berkarakter dan tanggap terhadap perkembangan IPTEK.

Dalam praktiknya pencapaian visi tersebut tidaklah mudah, perlu pengkajian, penelitian, evaluasi dan tindakan pencapaian. Beberapa permasalahan yang ditemukan adalah (1) Penggunaan modul praktikum yang ada dipandang masih kurang dalam mengarahkan proses perkuliahan mahasiswa secara mandiri. (2) Rendahnya kemandirian mahasiswa dalam kegiatan praktikum dipandang menjadi faktor utama penyebab rendahnya Keterampilan proses sains dan keterampilan sosial yang dimiliki mahasiswa. (3). Dibutuhkan modul praktikum yang dapat mandiri mengarahkan proses perkuliahan mahasiswa secara mandiri. (4) Perlu dibuat modul praktikum mandiri sebagai asesmen keterampilan proses sains dan keterampilan sosial mahasiswa. Berdasarkan identifkasi masalah tersebut, peneliti bermaksud untuk melakukan penelitian dengan judul "Pengembangan Modul Praktikum Mandiri sebagai Asesmen Keterampilan Proses Sains dan Keterampilan Sosial Mahasiswa".

\section{METODE/EKSPERIMEN}

\section{Metode Penelitian}

Metode yang digunakan dalam penelitian ini adalah jenis penelitian dan pengembangan, atau dikenal Research and Development (R\&D). Metode R\&D pada penelitian ini bertujuan untuk menghasilkan produk dan menguji kelayakan produk tersebut. Menurut Mulyatiningsih (2014:161), R\&D bertujuan untuk menghasilkan sebuah produk baru dengan melalui proses perancangan, penerapan, pengujian, dan dievaluasi sebelum digunakan untuk lingkungan yang lebih luas. 
Produk yang akan buat dalam penelitian ini adalah modul praktikum mandiri untuk mata kuliah Praktikum Fisika Dasar II. Adapun model pengembangan media pembelajaran yang digunakan adalah model 4-D (four $D$ model) dikemukakan oleh Thiagarajan (1974) dalam (Trianto, 2010:93). Model ini terdiri dari 4 tahap pengembangan, yaitu Define, Design, Develop dan Disseminate. Pengembangan mudul praktikum mandiri menggunakan model 4-D dengan didasarkan alasan sebagai berikut:

1. Perangkat pembelajaran model 4-D lebih runtun.

2. Adanya tahap validasi dan uji coba menjadikan draf yang dihasilkan lebih sempurna. Namun dalam penelitian ini hanya dibatasi sampai tahap pengembangan (Develop).

Flow Chart alur penelitian ini dapat dilihat pada gambar 1.

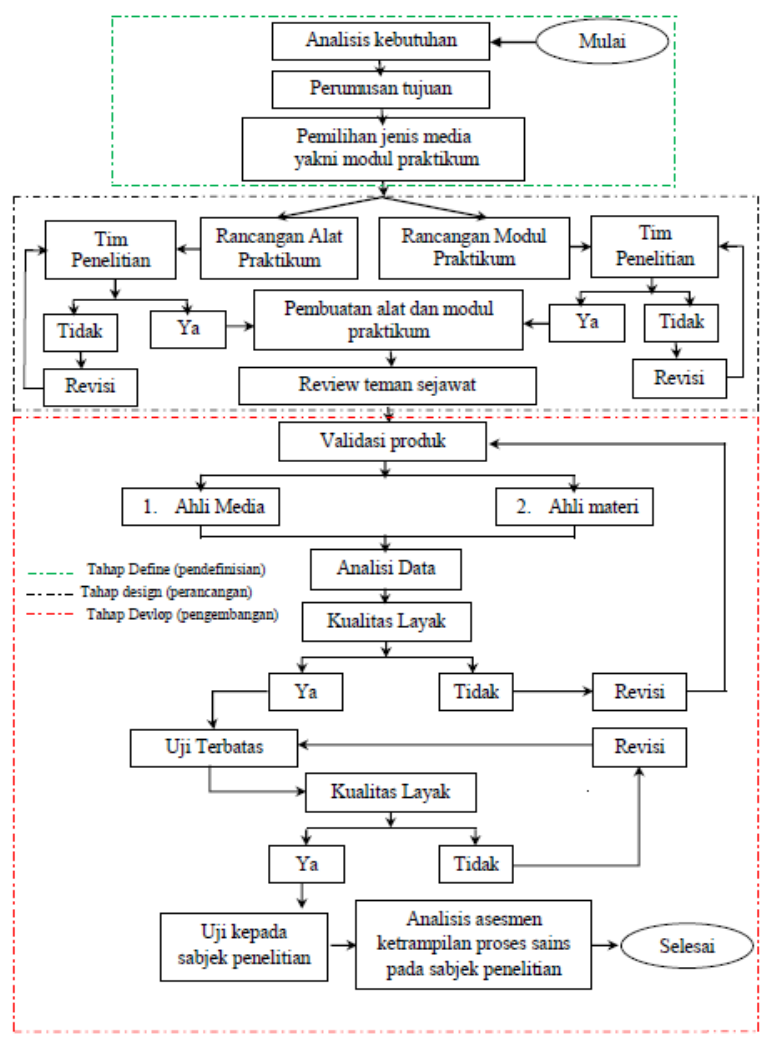

Gambar 1. Flow Chart Penelitian

\section{Deskripsi Subjek dan Waktu Penelitian}

Penelitian ini dilakukan di Sekolah Tinggi

Keguruan dan IImu Pendidikan Nurul Huda dengan subjek mahasiswa Program Studi Pendidikan Fisika semester 2 yang bejumlah
19 mahasiswa. Penelitian ini akan dilaksanakan pada bulan Maret sampai dengan bulan April 2017 yang mengambil waktu efektif perkuliahan semester genap.

\section{Teknik Pengumpulan Data}

Teknik pengumpulan data dalam penelitian dapat dilakukan dengan beberapa metode diantaranya interview (wawancara), kuesioner (angket), observasi (pengamatan) dan gabungan ketiganya Sugiyono (2016:309). Teknik pengumpulan data yang digunakan dalam penelitian ini adalah:

1. Kuesioner (Angket)

Menurut Riduwan (2013:26), Angket adalah daftar pertanyaan yang diberikan kepada orang lain yang bersedia memberikan respon sesuai dengan permintaan peneliti. Tujuan penyebaran angket ialah mencari informasi yang lengkap mengenai suatu masalah dari responden tanpa merasa khawatir bila responden memberikan jawaban yang tidak sesuai dengan kenyataan dalam pengisian daftar pertanyaan. Angket pada penelitian ini ditujukan kepada teman sejawat sebagai penilaian kelayakan media, dan penilaian kelayakan materi, serta kepada mahasiswa sebagai subjek penelitian.

2. Observasi

Metode pengambilan data melalu lembar observasi dalam penelitian ini dilakukan sebagai asesmen untuk melihat ketercapaian keterampilan proses sains mahasiswa saat kegiatan perkuliahan melalui modul praktikum mandiri. Lembar observasi dalam penelitian ini berbentuk penilaian skala (rating scale). Observasi dilakukan kepada subjek penelitian dari kegiatan awal sampai akhir pembelajaran praktikum dengan aspek penilaian (1) mengamati (2) mengklasifikasikan (3) melakukan eksperimen (4) menginterpretasikan data eksperimen (5) memprediksi (6) mengkomunikasikan.

\section{Instrumen Penelitian}

Instrumen penelitian yang digunakan dalam penelitian ini berupa angket diberikan 
kepada teman sejawat untuk menilai kelayakan materi dan media dalam modul praktikum mandiri yang dibuat oleh peneliti. Angket penilaian kebermanfaatan diberikan kepada pengguna sebagai subjek (responden) penelitian. Berikut ini angket yang digunakan dalam penelitian:

\section{Angket Kelayakan Modul Praktikum Mandiri}

Angket kelayakan modul praktikum mandiri untuk teman sejawat dengan penilaian kelayakan media dan kelayakan materi pada modul praktikum terdiri dari 17 butir penilaian yang terbagi menjadi enam aspek kualitas. Indikator penilaian dapat dilihat pada tabel 1 .

Tabel 1. Kisi-kisi angket untuk ahli materi

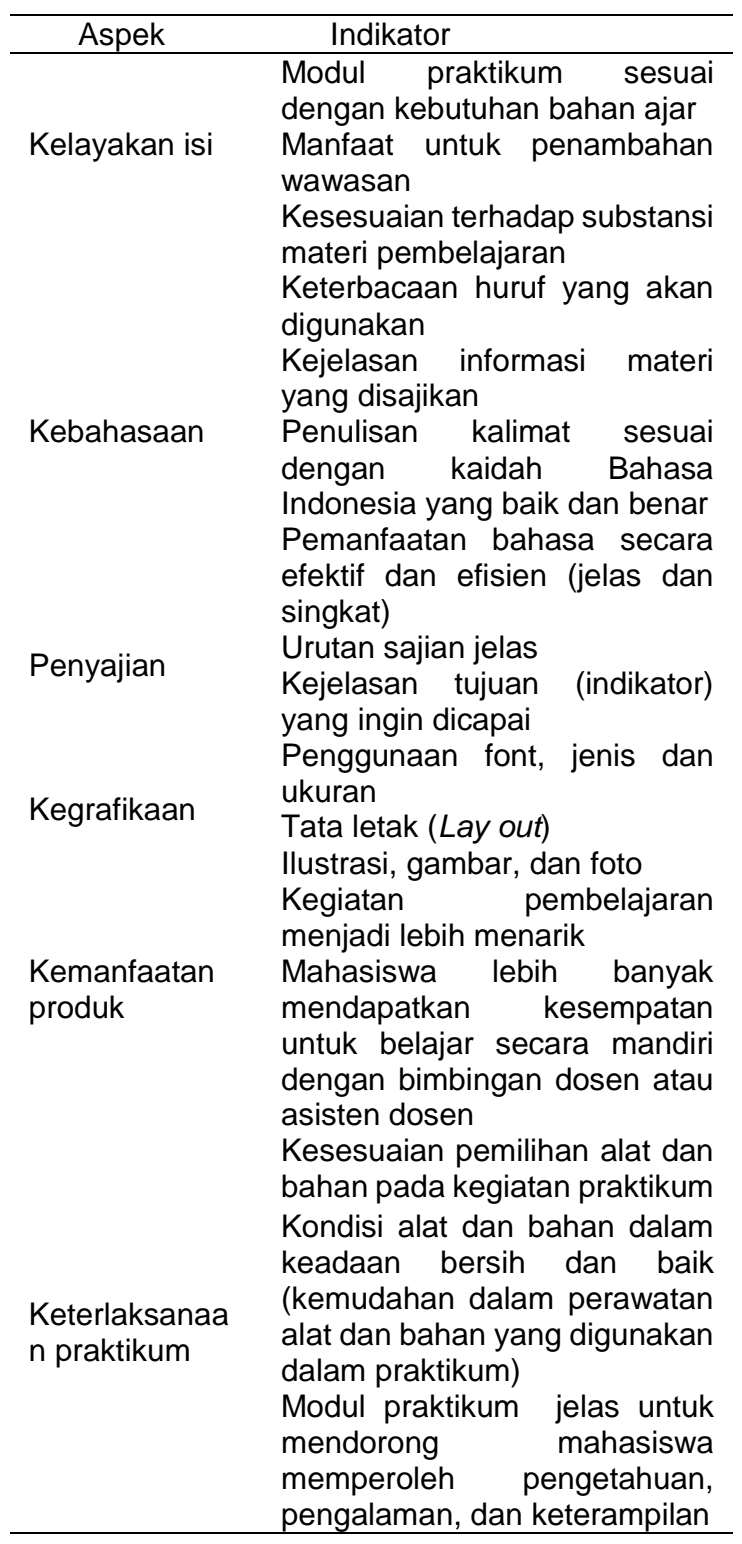

2. Angket Kelayakan Modul Praktikum Untuk Pengguna

Angket kelayakan modul praktikum untuk pengguna terdiri dari 15 butir penilaian yang terbagi menjadi enam aspek kualitas. Kisi-kisi angket untuk pengguna dapat dilihat pada tabel 2.

Tabel 2. Kisi-kisi angket untuk pengguna modul praktikum

\begin{tabular}{|c|c|}
\hline Aspek & Indikator \\
\hline \multirow{5}{*}{$\begin{array}{l}\text { Kelayakan } \\
\text { isi }\end{array}$} & $\begin{array}{l}\text { Modul praktikum sesuai dengan } \\
\text { kebutuhan bahan ajar }\end{array}$ \\
\hline & $\begin{array}{l}\text { Manfaat untuk penambahan } \\
\text { wawasan }\end{array}$ \\
\hline & $\begin{array}{l}\text { Kesesuaian terhadap substansi } \\
\text { materi pembelajaran }\end{array}$ \\
\hline & $\begin{array}{l}\text { Keterbacaan huruf yang akan } \\
\text { digunakan }\end{array}$ \\
\hline & $\begin{array}{l}\text { Kejelasan informasi materi yang } \\
\text { disajikan }\end{array}$ \\
\hline \multirow[t]{2}{*}{ Kebahasaan } & $\begin{array}{l}\text { Penulisan kalimat sesuai dengan } \\
\text { kaidah Bahasa Indonesia yang } \\
\text { baik dan benar }\end{array}$ \\
\hline & $\begin{array}{l}\text { Pemanfaatan bahasa secara } \\
\text { efektif dan efisien (jelas dan } \\
\text { singkat) }\end{array}$ \\
\hline \multirow{3}{*}{ Penyajian } & Urutan sajian jelas \\
\hline & $\begin{array}{l}\text { Kejelasan tujuan (indikator) yang } \\
\text { ingin dicapai }\end{array}$ \\
\hline & $\begin{array}{l}\text { Penggunaan font, jenis dan } \\
\text { ukuran }\end{array}$ \\
\hline \multirow{3}{*}{ Kegrafikaan } & Tata letak (Lay out) \\
\hline & Ilustrasi, gambar, dan foto \\
\hline & $\begin{array}{l}\text { Kegiatan pembelajaran menjadi } \\
\text { lebih menarik }\end{array}$ \\
\hline $\begin{array}{l}\text { Kemanfaata } \\
\mathrm{n} \text { produk }\end{array}$ & $\begin{array}{l}\text { Mahasiswa lebih banyak } \\
\text { mendapatkan kesempatan untuk } \\
\text { belajar secara mandiri dengan } \\
\text { bimbingan dosen atau asisten } \\
\text { dosen }\end{array}$ \\
\hline
\end{tabular}

3. Lembar Observasi Penilaian Keterampilan Sains Mahasiswa

Observasi dilakukan kepada subjek penelitian dari kegiatan awal sampai akhir praktikum dengan 5 aspek penilaian. Indikator penilaian pada lembar observasi keterampilan proses sains dapat disajikan pada tabel 3 . 
Tabel 3. Indikator penilaian keterampilan proses sains mahasiswa

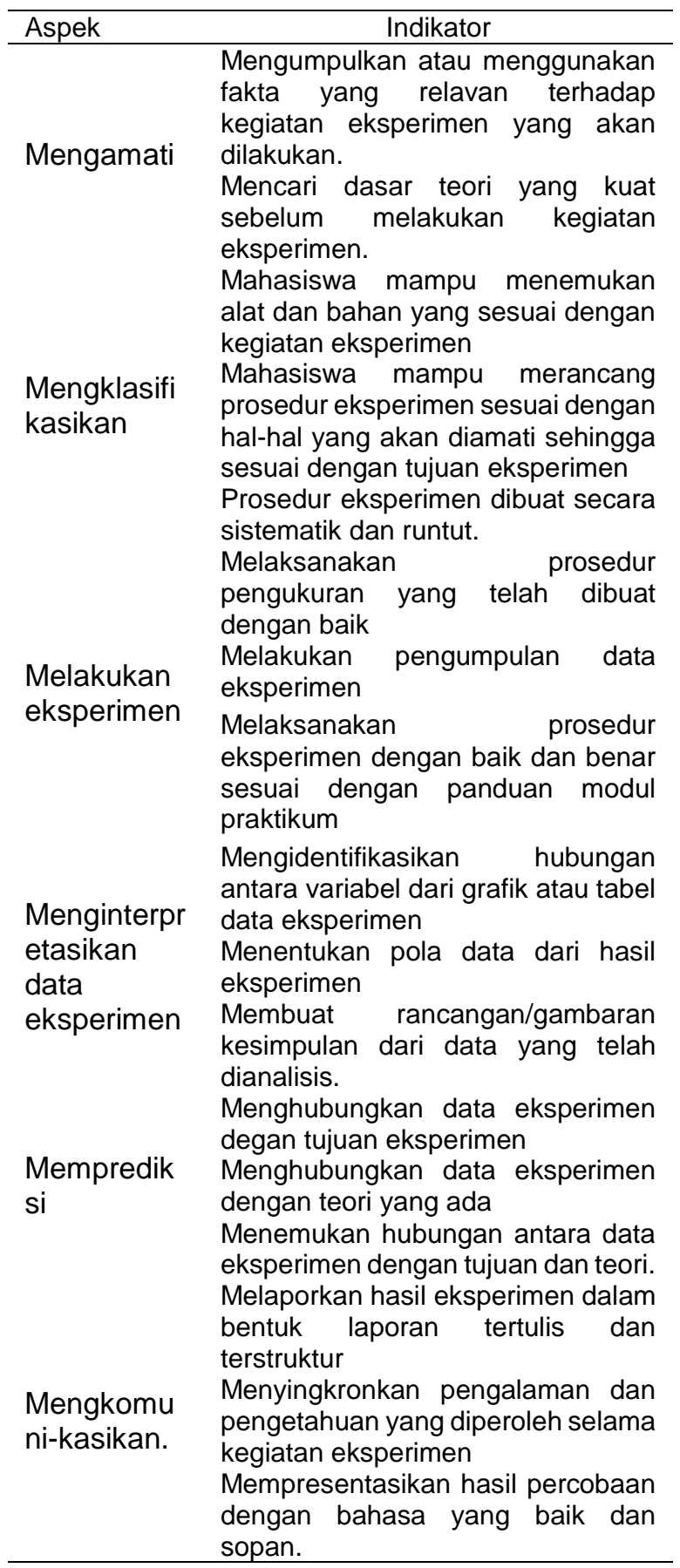

4. Lembar Observasi Penilaian Keterampilan Sains Mahasiswa

Observasi dilakukan kepada subjek penelitian saat kegiatan praktikum berlangsung dan kegiatan diskusi hasil praktikum dengan 3 aspek penilaian. Indikator penilaian pada lembar observasi keterampilan sosial dapat disajikan pada tabel 4 .
Tabel 4. Indikator penilaian keterampilan sosial mahasiswa

\begin{tabular}{|c|c|}
\hline Aspek & Indikator \\
\hline $\begin{array}{l}\text { Keterampilan } \\
\text { bekerjasama } \\
\text { dalam satu } \\
\text { kelompok }\end{array}$ & $\begin{array}{l}\text { Mahasiswa pada setiap } \\
\text { kelompok saling } \\
\text { berkoordinasi (sebelum, } \\
\text { saat, dan setelah) kegiatan } \\
\text { praktikum berlangsung. } \\
\text { Mahasiswa saling } \\
\text { membantu dalam kegiatan } \\
\text { diskusi dalam kelompok. }\end{array}$ \\
\hline $\begin{array}{l}\text { Keterampilan } \\
\text { bertanya }\end{array}$ & $\begin{array}{l}\text { Mahasiswa menggunakan } \\
\text { bahasa yang baik dan } \\
\text { sopan saat mengajukan } \\
\text { pertanyaan } \\
\text { Mahasiswa bertanya tidak } \\
\text { hanya sekedar menguji } \\
\text { kemampuan mahasiswa } \\
\text { kelompok lain }\end{array}$ \\
\hline $\begin{array}{l}\text { Keterampilan } \\
\text { menghargai } \\
\text { pendapat } \\
\text { kelompok lain }\end{array}$ & $\begin{array}{l}\text { Mahasiswa dalam memberi } \\
\text { tanggapan menggunakan } \\
\text { bahasa yang baik dan } \\
\text { sopan } \\
\text { Mahasiswarak } \\
\text { memaksakan kebenaran } \\
\text { pada pendapatnya sendiri }\end{array}$ \\
\hline
\end{tabular}

\section{Teknik Analisis Data}

Jenis data yang didapatkan pada penelitian ini adalah data kualitatif dan kuantitatif. Data kualitatif didapatkan dari saran perbaikan produk oleh teman sejawat untuk kelayakan materi dan media dan pengguna sebagai subjek penelitian. Sedangkan data kuantitatif diperoleh dari hasil angket kelayakan media dan kelayakan materi, dan respon pengguna. Kriteria pemberian skor untuk angket dari huruf menjadi angka dengan ketentuan yang dapat dilihat dalam tabel 5 .

Tabel 5. Konversi pemberian skor dari huruf ke angka

\begin{tabular}{lll}
\hline No & Skor & Kriteria \\
\hline 1 & Sangat Baik (SB) & 4 \\
2 & Baik (B) & 3 \\
3 & Cukup (C) & 2 \\
4 & Tidak Baik (TB) & 1 \\
\hline
\end{tabular}

Untuk menghitung skor rata-rata setiap kriteria yang diambil digunakan persamaan sebagai berikut (Sugiono, 2010). 


$$
\bar{X}=\frac{\sum_{i=1}^{N} X_{i}}{N}
$$

dengan $\bar{X}$ adalah skor rata-rata tiap sub aspek kualitas, $\sum_{i=1}^{N} X_{i}$ merupakan jumlah skor tiap sub aspek, dan $\mathrm{N}$ adalah jumlah penilai. Putro (2017:238) mengemukakan bahwa data ini menggunakan statistik deskriptif kuantitatif yang dikonversikan menjadi skala 4 dengan menggunakan acuan konversi pada tabel 6 .

Tabel 6. Klasifikasi Penilaian Kelayakan Media Pembelajaran Skala 4

\begin{tabular}{ccll}
\hline Rumus & $\begin{array}{c}\text { Rerata } \\
\text { Skor }\end{array}$ & Klasifikasi & Nilai \\
\hline $\mathrm{X}>\mathrm{X}_{\mathrm{i}}+1,8 \times \mathrm{S}_{\mathrm{bi}}$ & $\mathrm{X}>3,4$ & Sangat & 4 \\
$\mathrm{X}_{\mathrm{i}}+0,6 \times \mathrm{S}_{\mathrm{bi}}<\mathrm{X}$ & $<2,8-3,4$ & Baik & 3 \\
$\leq \mathrm{X}_{\mathrm{i}}+1,8 \times \mathrm{S}_{\mathrm{bi}}$ & & & \\
$\mathrm{X}_{\mathrm{i}}-0,6 \times \mathrm{S}_{\mathrm{bi}}<\mathrm{X}$ & $<2,2-2,8$ & Cukup & 2 \\
$\leq \mathrm{X}_{\mathrm{i}}+0,6 \times \mathrm{S}_{\mathrm{bi}}$ & & \\
$\mathrm{X}_{\mathrm{i}}-1,8 \times \mathrm{S}_{\mathrm{bi}}<\mathrm{X}$ & $<1,6-2,2$ & Kurang & 1 \\
$\leq \mathrm{X}_{\mathrm{i}}-0,6 \times \mathrm{S}_{\mathrm{bi}}$ & \multicolumn{3}{l}{ Sumber : Putro $(2017: 238)$} \\
\multicolumn{5}{l}{ Keterangan Klasifikasi: }
\end{tabular}

1. Klasifikasi sangat baik $(>3,4)$ dapat diartikan bahwa media pembelajaran tersebut sangat layak digunakan dalam pembelajaran.

2. Klasifikasi baik $(>2,8-3,4)$ dapat diartikan bahwa media pembelajaran tersebut layak digunakan dalam pembelajaran.

3. Klasifikasi cukup $(>2,2-2,8)$ dapat diartikan bahwa media pembelajaran tersebut cukup layak digunakan dalam pembelajaran.

4. Klasifikasi kurang $(>1,6-2,2)$ dapat diartikan bahwa media pembelajaran tersebut tidak layak digunakan dalam pembelajaran.

Ketentuan :

$X_{i}=\frac{1}{2}\left(S_{m x i}+S_{m n i}\right)$

$S_{b i}=\frac{1}{6}\left(S_{m x i}-S_{m n i}\right)$

Keterangan:
$X=$
Skor empiris
$X_{i}=$ Rerata ideal
$S_{b i}=\quad$ Simpangan baku ideal

$$
\begin{array}{ll}
S_{m \times i}= & \text { Skor maksimum ideal } \\
S_{m n i}= & \text { Skor minimum ideal }
\end{array}
$$

\section{HASIL DAN PEMBAHASAN}

Penelitian ini bertujuan mengetahui kelayakan, keterlaksanaan, dan asesmen keterampilan proses sains serta keterampilan sosial pada pengembangan modul praktikum mandiri untuk mahasiswa STKIP Nurul Huda Sukaraja Program Studi Pendidikan Fisika semester 2. Secara umum prosedur pengembangan produk dalam penelitian ini dapat dilihat pada gambar 1. Penelitian pengembangan ini meliputi analisis potensi, kebutuhan, dan masalah, perancangan desain produk, validasi produk dengan teman sejawat, revisi desain, uji coba terbatas, menguji kepada subjek penelitian, analisis asesmen Keterampilan proses sains. Berikut uraian tahapan dari data hasil penelitian.

\section{Hasil Penilaian Kelayakan Modul Praktikum Mandiri}

Data hasil perhitungan validasi kelayakan media pembelajaran dan materi pembelajaran pada modul praktikum mandiri dapat pada tabel 7 .

Tabel 7. Data hasil penilaian kelayakan modul praktikum mandiri.

\begin{tabular}{llcll}
\hline No & \multicolumn{1}{c}{ Aspek } & $\begin{array}{c}\text { Rerat } \\
\text { a } \\
\text { Skor }\end{array}$ & Kategori & $\begin{array}{c}\text { Perse } \\
\mathrm{n}\end{array}$ \\
\hline 1 & Kelayakan isi & 3,33 & Baik & $83 \%$ \\
2 & Kebahasaan & 3,75 & $\begin{array}{l}\text { Sangat } \\
\text { Baik }\end{array}$ & $94 \%$ \\
3 & Penyajian & 3,00 & Baik & $75 \%$ \\
4 & Kegrafikaan & 4,00 & $\begin{array}{l}\text { Sangat } \\
\text { Baik }\end{array}$ & $100 \%$ \\
5 & $\begin{array}{l}\text { Kemanfaatan } \\
\text { Produk }\end{array}$ & 4,00 & $\begin{array}{l}\text { Sangat } \\
\text { Baik }\end{array}$ & $100 \%$ \\
6 & $\begin{array}{l}\text { Keterlaksanaa } \\
\text { n praktikum }\end{array}$ & 3,65 & $\begin{array}{l}\text { Sangat } \\
\text { Baik }\end{array}$ & $96 \%$ \\
Rerata Skor Total & 3,65 & $\begin{array}{l}\text { Sangat } \\
\text { Baik }\end{array}$ & $91 \%$ \\
\hline
\end{tabular}

Tabel 7 menunjukkan bahwa, dari penilaian keenam aspek yang dilakukan oleh dua teman sejawat diperoleh rerata skor total adalah 3,65. Berdasarkan pengkualifikasian nilai sesuai dengan tabel 6 , maka skor yang diperoleh termasuk dalam kategori "Sangat Baik" sehingga perancangan modul praktikum 
mandiri selanjutnya dapat digunakan dalam kegiatan perkuliahan untuk mengukur Keterampilan proses sains yang dimiliki mahasiswa saat melakukan praktikum. Data pada tabel 7 secara sederhana dapat digambarkan melalui diagram sebagai berikut:

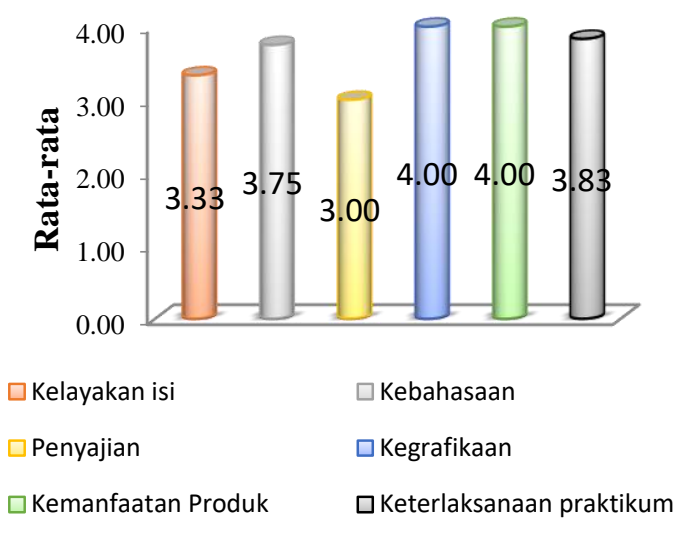

Gambar 2. Diagram penilaian kelayakan modul praktikum mandiri.

Berdasarkan gambar 2 dapat diketahui bahwa penilaian keenam aspek tersebut menghasilkan rerata skor 1) 3,33 pada kelayakan isi 2) 3,75 pada pembahasan 3) 3,00 pada penyajian 4) 4,00 pada kegrafikan 5) 4,00 pada kemanfaatan produk dan 6) 3,65 pada keterlaksanaan praktikum. Kurangnya kejelasan tujuan (indikator) yang ingin dicapai yang terdapat di dalam modul praktikum sehingga pada aspek penyajian mendapatkan rata-rata terendah dibandingkan dengan aspek kegrafikaan dan kemanfaatan produk. Aspek kegrafikaan dan kemanfaatan produk lebih unggul karena penggunaan font, jenis, ukuran dan tata letak gambar yang mudah dipahami bagi mahasiswa dan produk yang dihasilkan peneliti dapat bermanfaat bagi pengguna sehingga mahasiswa lebih banyak mendapatkan kesempatan untuk belajar secara mandiri dengan bimbingan dosen atau asisten dosen.

\section{Hasil Kelayakan Modul Praktikum Mandiri oleh Pengguna}

Data hasil respon pengguna modul praktikum mandiri terhadap aspek yang dinilai dapat dilihat pada tabel 8 .
Tabel 8. Data hasil respon uji coba pengguna modul praktikum

\begin{tabular}{|c|c|c|c|c|}
\hline No & Aspek & $\begin{array}{c}\text { Rerata } \\
\text { Skor }\end{array}$ & Kategori & Persen \\
\hline 1 & Kelayakan Isi & 3,67 & $\begin{array}{l}\text { Sangat } \\
\text { Baik }\end{array}$ & $92 \%$ \\
\hline 2 & Kebahasaan & 3,53 & $\begin{array}{l}\text { Sangat } \\
\text { Baik }\end{array}$ & $88 \%$ \\
\hline 3 & Penyajian & 3,68 & $\begin{array}{l}\text { Sangat } \\
\text { Baik }\end{array}$ & $92 \%$ \\
\hline 4 & Kegrafikaan & 3,56 & $\begin{array}{l}\text { Sangat } \\
\text { Baik }\end{array}$ & $89 \%$ \\
\hline 5 & $\begin{array}{l}\text { Kemanfaatan } \\
\text { Produk }\end{array}$ & 3,68 & $\begin{array}{l}\text { Sangat } \\
\text { Baik }\end{array}$ & $92 \%$ \\
\hline 6 & $\begin{array}{l}\text { Keterlaksanaa } \\
\text { n Praktikum }\end{array}$ & 3,73 & $\begin{array}{l}\text { Sangat } \\
\text { Baik }\end{array}$ & $93 \%$ \\
\hline \multicolumn{2}{|c|}{ Rerata Skor Total } & 3,64 & $\begin{array}{l}\text { Sangat } \\
\text { Baik }\end{array}$ & $91 \%$ \\
\hline
\end{tabular}

Tabel 8 menunjukan bahwa dari penilaian keenam aspek tersebut yang dilakukan oleh 19 mahasiswa sebagai pengguna modul praktikum diperoleh rerata respon penilaian mahasiswa pada uji coba pengguna adalah 3,64. Maka skor yang diperoleh termasuk dalam kategori "Sangat Baik". Data hasil uji pengguna pada tabel 8 dapat digambarkan dalam diagram sebagai berikut:

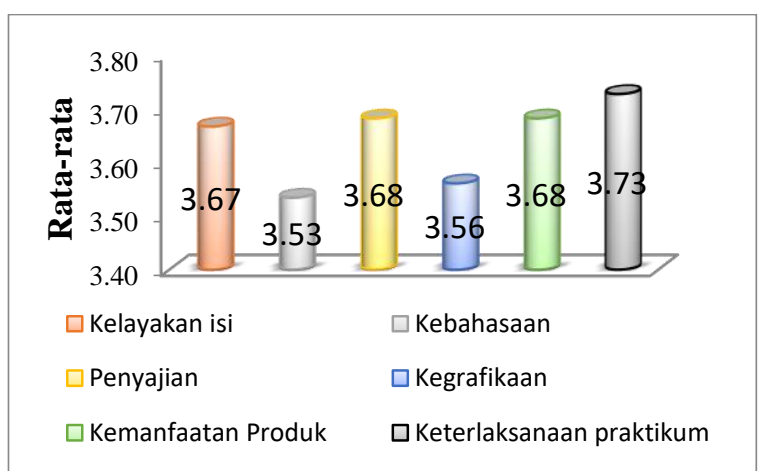

Gambar 3. Diagram data uji pengguna modul praktikum mandiri

Berdasarkan gambar 3 dapat diketahui bahwa penilaian dari kedua aspek tersebut menghasilkan rerata skor 1) 3,67 pada kelayakan isi 2) 3,53 pada pembahasan 3) 3,68 pada penyajian 4) 3,56 pada kegrafikan 5) 3,68 pada kemanfaatan produk dan 6) 3,73 pada keterlaksanaan praktikum. Setelah direvisi sesuai dengan hasil validasi ahli materi maka adanya alat dan modul praktikum sebagai penunjang untuk terlaksananya praktikum mendorong mahasiswa memperoleh 
pengetahuan, pengalaman, dan keterampilan pada aspek keterlaksanaan praktikum lebih unggul dibandingkan dengan aspek kebahasaan karena kurangnya kejelasan informasi materi yang disajikan.

\section{Hasil Asesmen Keterampilan Proses Sains Mahasiswa}

Data hasil asesmen keterampilan proses sains mahasiswa dalam kegiatan eksperimen menggunakan modul praktikum mandiri dapat dilihat pada tabel 9 .

Tabel 9. Data hasil asesmen keterampilan proses sains mahasiswa

\begin{tabular}{|c|c|c|c|c|}
\hline No & Aspek & $\begin{array}{l}\text { rata- } \\
\text { rata }\end{array}$ & Kriteria & Persen \\
\hline 1 & Mengamati & 3,18 & Baik & $80 \%$ \\
\hline 2 & $\begin{array}{l}\text { Mengklasifikasikan } \\
\text { Melakukan }\end{array}$ & 3,25 & Baik & $81 \%$ \\
\hline 3 & $\begin{array}{l}\text { Eksperimen } \\
\text { Menginterpretasikan }\end{array}$ & 3,23 & Baik & $81 \%$ \\
\hline 4 & Data Eksperimen & 2,98 & Baik & $75 \%$ \\
\hline 5 & Memprediksi & 3,19 & Baik & $80 \%$ \\
\hline 6 & Mengkomunikasikan. & 3,30 & Baik & $82 \%$ \\
\hline \multicolumn{2}{|c|}{ Rerata total } & 3,19 & Baik & $80 \%$ \\
\hline
\end{tabular}

Berdasarkan tabel 9, dapat dijelaskan bahwa secara keseluruhan asesmen keterampilan proses sains yang dimiliki mahasiswa baik, penilaian tertinggi dari keterampilan proses sains yang dimiliki mahasiswa yaitu pada aspek mengkomunikasikan, karena pada tahap ini mahasiswa sudah mendapat arahan dan masukkan dari dosen pengampu terkait dengan eksperimen yang sudah dilakukan, sehingga dalam mempresentasikan atau melaporkan hasil kegiatan eksperimen sudah sesuai dengan tujuan eksperimen. Namun asesmen aspek menginterpretasikan data eksperimen pada Keterampilan proses sains memiliki nilai rata-rata paling kecil, dengan nilai 2,98. Berdasarkan hasil evaluasi dari peneliti pada tahap menginterpretasikan data eksperimen, mahasiswa masih belum memahami keterkaitan variabel-variabel penting dalam data eksperimen sehingga dalam penyimpulan dari data analisis yang sudah dikerjakan belum sesuai dengan tujuan eksperimen.

\section{Hasil Asesmen Keterampilan Sosial Mahasiswa}

Data hasil asesmen keterampilan sosial mahasiswa dalam kegiatan eksperimen menggunakan modul praktikum mandiri dapat dilihat pada tabel 10 .

Tabel 10.Data hasil asesmen keterampilan sosial mahasiswa

\begin{tabular}{|c|c|c|c|c|}
\hline No & Aspek & $\begin{array}{l}\text { Rata- } \\
\text { rata }\end{array}$ & Kriteria & Persentase \\
\hline 1 & $\begin{array}{l}\text { Keterampilan } \\
\text { bekerjasama } \\
\text { dalam kelompok }\end{array}$ & 3,50 & $\begin{array}{l}\text { Sangat } \\
\text { Baik }\end{array}$ & $88 \%$ \\
\hline 2 & $\begin{array}{l}\text { Keterampilan } \\
\text { bertanya }\end{array}$ & 3,61 & $\begin{array}{l}\text { Sangat } \\
\text { Baik }\end{array}$ & $90 \%$ \\
\hline 3 & $\begin{array}{l}\text { Keterampilan } \\
\text { menghargai } \\
\text { pendapat } \\
\text { kelompok lain }\end{array}$ & 3,47 & $\begin{array}{l}\text { Sangat } \\
\text { Baik }\end{array}$ & $87 \%$ \\
\hline \multicolumn{2}{|c|}{ Rerata Total } & 3,53 & $\begin{array}{l}\text { Sangat } \\
\text { Baik }\end{array}$ & $88 \%$ \\
\hline
\end{tabular}

Berdasarkan tabel 10, dapat dijelaskan bahwa secara keseluruhan asesmen keterampilan sosial mahasiswa sangat baik, dapat dilihat dari nilai rerata total dari aspek penilaian keterampilan sosial mahasiswa dengan nilai 3,53 pada perbandingan skala 4. Penilaian tertinggi dari keterampilan sosial yang dimiliki mahasiswa yaitu pada aspek keterampilan bertanya dengan nilai 3,61. Dan penilaian terendah yaitu pada aspek keterampilan menghargai pendapat kelompok lain dengan nilai 3,47.

Dari tabel 10 dapat dilihat bahwa kemampuan sosial mahasiswa yang mengindikasikan kecerdasan emosional mahasiswa seluruhnya sudah berada pada tingkatan yang sangat baik. Hal ini menyiratkan bahwa mahasiswa sudah mampu mengatasi masalah-masalah sosial berupa perbedaan individu yang terjadi selama praktikum, seperti perbedaan pendapat, perbedaan pemikiran, perbedaan karakter atau kepribadian, perbedaan temperamen, perbedaan intelegensi, dan perbedaan gaya belajar.

Jika diamati lebih lanjut, aspek menghargai pendapat kelompok lain memiliki presentase yang paling kecil. Ini dapat dimaklumi karena adanya daya saing mahasiswa terhadap penilaian keaktifan yang dilakukan dosen selama diskusi berlangsung. Ini merupakan dampak positif dibuatkannya modul praktikum mandiri ini, juga mengindikasikan bahwa sasaran dari 
dikembangkannya modul praktikum mandiri ini sudah tercapai. Karena mahasiswa dapat menemukan kebenaran melalui keterampilan proses sains, dan juga menemukan keseimbangan emosional melalui keterampilan sosial.

\section{PENUTUP}

\section{Kesimpulan}

Berdasarkan hasil kajian penelitian, kesimpulan dari penelitian pengembangan ini adalah sebagai berikut:

1. Dihasilkan modul praktikum mandiri secara keseluruhan dari penilaian aspek kelayakan isi, kebahasaan, kegrafikan, kemanfaatan produk, dan keterlaksanaan pratikum diperoleh rerata skor total adalah 3,65. Nilai tersebut mengindikasikan bahwa modul yang dikembangkan sangat layak untuk digunakan dalam proses perkuliahan.

2. Dari hasil respon uji pengguna secara keseluruhan penilaian aspek kelayakan isi, kebahasaan, kegrafikan, kemanfaatan produk, dan keterlaksanaan pratikum diperoleh rerata skor total adalah 3,64. Penilaian dari subjek penelitian ini mengindikasikan bahwa modul praktikum mandiri sangat layak.

3. Hasil asesmen keterampilan proses sains yang diperoleh mahasiswa saat melakukan eksperimen menggunakan modul praktikum mandiri secara umum bernilai baik. Rincian asesmen keterampilan proses sains untuk setiap aspek diperoleh (1) mengamati nilai rata-rata 3,18 (2) mengklasifikasikan nilai rata-rata 3,25 (3) melakukan eksperimen $3,23 \quad$ (4) menginterpretasikan data eksperimen 2,98 (5) memprediksi nilai rata-rata 3,19 (6) mengkomunikasikan nilai rata-rata 3,30.

4. Hasil asesmen keterampilan sosial yang diperoleh mahasiswa saat melakukan eksperimen menggunakan modul praktikum mandiri secara umum dapat diindikasikan sangat baik dengan nilai rerata total 3,53. Rincian asesmen keterampilan sosial untuk setiap aspek diperoleh 1 Keterampilan bekerjasama

$\begin{array}{llll}\text { dalam satu } & \text { kelompok } & 3,50, & (2) \\ \text { keterampilan } & \text { bertanya } & 3,61 & (3) \\ \text { Keterampilan menghargai } & \text { pendapat } \\ \text { kelompok lain } 3,47 .\end{array}$

\section{Saran}

Adapun saran peneliti tentang pemanfaatan dan penelitian produk selanjutnya adalah:

1. Pemanfaatan

a. Peneliti menyarankan dalam penggunaan modul praktikum mandiri sebagai asesmen keterampilan proses sains dosen penggampu atau laborat harus memiliki tim penilai keterampilan proses sains disesuaikan dengan proporsi julmah mahasiswa yang mengikuti kegiatan eksperimen agar dapat memberi penilaian yang lebih objektif.

b. Ketika menggunakan modul praktikum mandiri ini dosen atau laborat harus memberikan gambaran singkat sebagai dasar untuk menggali potensi mahasiswa secara mandiri, tanpa merusak alat praktikum dan keluar dari tujuan praktikum yang sudah ditetapkan di dalam judul praktikum masing-masing.

c. Rubrik asesmen keterampilan proses sains dan keterampilan sosial pada lembar observasi hanya dapat digunakan ketika mahasiswa melakukan praktikum dan diskusi hasil data praktikum.

2. Penelitian produk lanjutan.

Penelitian produk lanjutan dalam pengembangannya dapat di kombinasikan dengan model, strategi, atau metode pembelajaran perkuliahan yang relaven dengan kegiatan praktikum agar asesmen keterampilan proses sains dapat dikembangkan lebih luas.

\section{UCAPAN TERIMAKASIH}

Ucapan terimakasih peneliti ditujukan kepada institusi STKIP Nurul Huda Sukaraja 
yang sudah mewadahi dan memfasilitasi kebutuhan peneliti saat penelitian berlangsung. Selain itu peneliti juga mengucapkan terimakasih kepada Bapak Effendi, M.Pd. dan Saifur Rohim, S.Si. selaku teman sejawat peneliti yang memberikan masukan terhadap perancangan modul praktikum mandiri yang peneliti kembangkan. Dan yang terakhir peneliti berterimakasih kepada Fitri Mariani, Buhrotul Zulfi, dan Mar'atus Sholihah yang sudah membantu peneliti dalam pelaksanaan penelitian.

\section{DAFTAR PUSTAKA}

Depdikbud. (2013). Permendikbud No.54 tahun 2013 tentang SKL. Jakarta: Depdikbud.

Isriani. (2012). Strategi Pembelajaran Terpadu. Yogyakarta: Familia.

Jihad. (2010). Evaluasi Pembelajaran. Yogyakarta: Multi Pressindo.

Mulyatiningsih, Endang. (2014). Metode Penelitian Terapan Bidang Pendidikan. Bandung: Alfabeta.

Putro, Eko Widiyoko. (2017). Evaluasi Program Pembelajaran. Yogyakarta: Pustaka Pelajar.

Riduwan. (2013). Skala Pengukuran Variabelvariabel Penelitian. Bandung : Alfabeta.

Rohman, Fatkhur. (2015). Rancang Bangun Eksperimen Penentuan Viskositas Udara Pada Variasi Suhu dan Kelembaban Medium dengan Memanfaatkan Program Tracker. Tesis. Yogyakarta: Universitas Ahmad Dahlan.

Sugiyono. (2016). Metode Penelitian Pendidikan. Bandung: Alfabeta.

(2010). Statistika untuk Penelitian. Bandung: Alfabeta.

Trianto. (2010). Model Pembelajaran Terpadu. Jakarta : Bumi Aksara.

Undang-Undang Sistem Pendidikan Nasional Nomor 20 Tahun 2003 Tentang Sistem Pendidikan Nasional. 